\begin{tabular}{c} 
Tersedia online di: http://ejournal-balitbang.kkp.go.id/index.php/bawal \\
e-mail:bawal.puslitbangkan@gmail.com \\
BAWAL wIDYA RISET PERIKANAN TANGKAP \\
Volume 8 Nomor 2 Agustus 2016 \\
p-ISSN: 1907-8226 \\
e-ISSN: 2502-6410 \\
BAWAL \\
Nomor Akreditasi: $620 /$ AU2/P2MI-LIPI/03/2015 \\
\hline \hline
\end{tabular}

\title{
HUBUNGAN ANTARA KELIMPAHAN MEROPLANKTON DENGAN KUALITAS PERAIRAN DI TELUK JAKARTA
}

\section{RELATIONSHIP BETWEEN ABUNDANCE OF MEROPLANKTON AND WATER QUALITY IN JAKARTA BAY}

\author{
Adriani Sri Nastiti*1, Masayu Rahmia Anwar Putri ${ }^{1}$ dan Sri Turni Hartati ${ }^{2}$ \\ ${ }^{1}$ Balai Penelitian Pemulihan dan Konservasi Sumberdaya Ikan, Jl.Cilalawi No.1. Jatiluhur - Purwakarta, Jawa Barat 41152, Indonesia \\ ${ }^{2}$ Pusat Penelitian dan Pengembangan Perikanan, J1. Pasir Putih II, Ancil Timur Jakarta Utara-14430, Indonesia \\ Teregistrasi I tanggal: 03 Mei 2016; Diterima setelah perbaikan tanggal: 10 Agustus 2016; \\ Disetujui terbit tanggal: 15 Agustus 2016
}

\begin{abstract}
ABSTRAK
Meroplankton adalah organisme akuatik yang sebagian dari daur hidupnya bersifat planktonik dan merupakan fase paling kritis karena belum dapat menghindar dari predator. Untuk tumbuh, meroplankton membutuhkan kualitas perairan yang sesuai dan kawasan yang terlindung. Penelitian ini bertujuan untuk memperoleh data dan informasi kelimpahan meroplankton dan kualitas perairan di Teluk Jakarta. Pengumpulan data dilakukan pada bulan April, Juni, Agustus dan Oktober 2009 (10 stasiun) serta April dan Juni 2010 (5 stasiun) dengan metode stratified sampling. Hasil identifikasi menunjukkan bahwa meroplankton di Teluk Jakarta tahun 2009, 2010 terdiri dari 4 kelompok yaitu:ikan, telur, udang dan kepiting. Komposisi meroplankton di Teluk Jakarta pada tahun 2009 dan 2010 didominasi oleh larva udang masing-masing sebesar 56,17-90,40\% dan 72,1-75,5\%. Kelimpahan larva udang tahun 2014 lebih rendah dibanding tahun 2009-2010. Kelimpahan larva udang dipengaruhi oleh $\mathrm{pH}$, salinitas, kecerahan dan suhu air.
\end{abstract}

Kata Kunci: Komposisi; meroplankton; kualitas perairan; Teluk Jakarta

\section{ABSTRACT}

Meroplankton are aquatic organisms that part of their life cycles was planktonic that need appropriate environmental conditions and protected area for escaping from predators. The research aims to examine the composition and abundance of meroplankton in Jakarta Bay. Sampling was conducted in Jakarta Bay on April, June, August and October 2009 (10 stations) and April and June 2010 (5 stations). The samples of meroplankton collected by stratified sampling method. The results showed that meroplankton in Jakarta Bay in 2009, 2010 consists of 4 groups: fish, eggs, shrimp and crab. Composition meroplankton in Jakarta Bay in 2009 and 2010 was dominated by shrimp larvae by $56.17-90.40 \%$ and from $72.1-75.5 \%$ respectively. The abundance of shrimp larvae probably correlated with $\mathrm{pH}$, salinity, terbudity and temperature of the water.

Keywoeds: Composition; meroplankton; water quality; Jakarta Bay

\section{PENDAHULUAN}

Meroplankton adalah organisme akuatik yang sebagian dari daur hidupnya bersifat planktonik, misalnya tahap larva dan telur. Meroplankton merupakan fase paling kritis karena belum dapat menghindar dari predator dan membutuhkan kualitas lingkungan yang sesuai untuk pertumbuhannya serta kawasan terlindung (Nybakken, 1992; Nontji, 2008). Variasi kelimpahan dan sebaran meroplankton pada suatu habitat merupakan informasi penting untuk memahami mekanisme dalam proses rekruitmen serta faktor-faktor yang mempengaruhinya (Mitchell, 1994, Quist et al., 2004; Shoji \& Tanaka, 2008).

Nontji (2008) menyatakan bahwa informasi mengenai meroplankton berguna untuk mengetahui daerah asuhan (nursery ground) dan daerah pemijahan (spawning ground) pada suatu kawasan perairan. Informasi tentang 
distribusi, kelimpahan dan pertumbuhan larva ikan di perairan laut merupakan hal penting yang diperlukan dalam pengelolaan perikanan terutama dalam hal perlindungan habitat seperti menetapkan daerah perlindungan laut (Marine Protected Area) dan kawasan perikanan refugia (Fisheries Refugia) (Van der Lingen \& Huggett, 2003). Faktor-faktor lingkungan laut yang diketahui mempengaruhi kehidupan hewan laut termasuk meroplankton adalah faktor fisik, kimiawi dan biologi.

Informasi mengenai kelimpahan dan komposisi plankton di Teluk Jakarta sudah banyak yang dipublikasikan, beberapa diantaranya adalah oleh Romimoharto\&Juwana (2004), Fachrul et al. (2005), Soedibjo (2006) dan Rahman (2011). Sebaliknya publikasi penelitian meroplankton di Teluk Jakarta belum banyak ditemukan. Berdasarkan uraian tersebut, kajian meroplankton di Teluk Jakarta pada tahun 2009 merupakan informasi awal yang penting sebagai dasar pengelolaan sumber daya ikan.
Penelitian ini bertujuan untuk mendapatkan informasi kelimpahan meroplankton dan hubungan antara kelimpahan meroplankton dengan kondisi kualitas air di teluk Jakarta. Diharapkan hasil penelitian ini dapat menjadi salah satu dasar untuk rekomendasi pengelolaan perikanan di Teluk Jakarta yang terkait dengan daerah suaka perikanan.

\section{BAHANDANMETODE Lokasi dan Waktu}

Pengambilan sampel meroplankton dan parameter oseanografi di Teluk Jakarta dilakukan pada tahun 2009 dan 2010. Tahun 2009 meliputi 10 stasiun pengamatan yang tersebar dari wilayah barat sampai timur pada April, Juni, Agustus dan Oktober kemudian tahun 2010 meliputi 5 stasiun pengamatan pada April dan Juni yang tersebar di wilayah timur Teluk Jakarta (Gambar 1). Koordinat stasiun penelitian dapat dilihat pada Tabel 1.

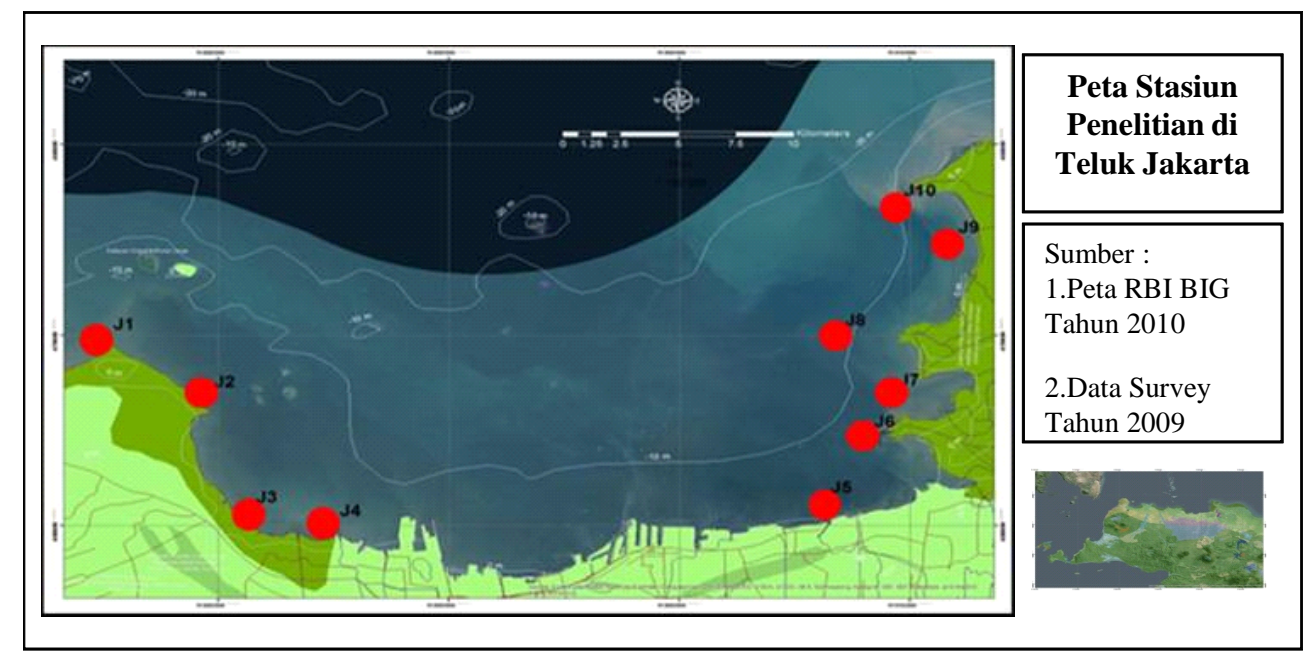

Gambar 1. Lokasi pengambilan sampel meroplankton dan oseanografi di Teluk Jakarta.

Figure 1. Map of meroplankton and oceanography sampling in Jakarta Bay.

Tabel 1. Posisi geografis lokasi pengambilan contoh di Teluk Jakarta

Table 1. Geographical position of sampling sites in Jakarta Bay

\begin{tabular}{|c|c|c|c|c|}
\hline \multirow{2}{*}{$\begin{array}{l}\text { No/ } \\
\text { No }\end{array}$} & \multirow{2}{*}{$\begin{array}{c}\text { Lokasi } \\
\text { Locations }\end{array}$} & \multirow{2}{*}{$\begin{array}{l}\text { Kode } \\
\text { Code }\end{array}$} & \multicolumn{2}{|c|}{ Posisi Geografis/Geographical position } \\
\hline & & & Lintang Selatan/Latitude & Bujur Timur/Longitude \\
\hline 1 & Tanjung Pasir & $\mathrm{J} 1$ & $06^{\circ} 00^{\prime} 35.6^{\prime \prime}$ & $106^{\circ} 40^{\prime} 28.5^{\prime \prime}$ \\
\hline 2 & Tanjung Rebo & $\mathrm{J} 2$ & $06^{\circ} 02^{\prime} 12.5^{\prime \prime}$ & $106^{\circ} 42^{\prime} 50.1^{\prime \prime}$ \\
\hline 3 & Muara Kamal & $\mathrm{J} 3$ & $06^{\circ} 05^{\prime} 26.3^{\prime \prime}$ & $106^{\circ} 43^{\prime} 49.6^{\prime \prime}$ \\
\hline 4 & Muara Angke & $\mathrm{J} 4$ & $06^{\circ} 05^{\prime} 49.8^{\prime \prime}$ & $106^{\circ} 4546.8^{\prime \prime}$ \\
\hline 5 & Muara Marunda & J5 & $0605^{\prime} 09.79 ”$ & 10657 '15.47” \\
\hline 6 & Muara Bekasi & J6 & $06^{\circ} 03^{\prime} 19^{\prime \prime}$ & $106^{\circ} 58^{\prime} 16^{\prime \prime}$ \\
\hline 7 & Muara Gembong & $\mathrm{J} 7$ & $06^{\circ} 02^{\prime} 09^{\prime \prime}$ & $106^{\circ} 58^{\prime} 51^{\prime \prime}$ \\
\hline 8 & Tanjung Gembong & $\mathrm{J} 8$ & $06^{\circ} 00^{\prime} 28.26^{\prime \prime}$ & $106^{\circ} 57^{\prime} 35.09^{\prime \prime}$ \\
\hline 9 & Teluk Karawang & J9 & $05^{\circ} 57^{\prime} 51.59 ”$ & $107^{\circ} 0014.06^{\prime \prime}$ \\
\hline 10 & Tanjung Karawang & $\mathrm{J} 10$ & $05^{\circ} 56^{\prime} 49^{\prime \prime}$ & $106^{\circ} 5858^{\prime \prime}$ \\
\hline
\end{tabular}




\section{Pengambilan Sampel}

Pengambilan sampel meroplankton menggunakan Bongo net (APHA, 2005), berukuran mata jaring $300 \mu \mathrm{m}$, diameter mulut $60 \mathrm{~cm}$ dan panjang $2 \mathrm{~m}$. Jaring bongo ditarik kapal dengan kecepatan 2 knot selamat 10 menit.
Sampel meroplankton disimpan dalam botol plastik, diawetkan dengan campuran formalin $4 \%$ dan boraks $2 \%$. Beberapa parameter oseanografi perairan seperti pada Tabel 2 juga turut diukur. Sampel air untuk analisis data oseanografi diambil dengan Nansen Bottle volume 1,5 liter.

Tabel 2. Parameter oceanografi yang diukur dan alat serta metode yang digunakan

Table 2. Oceanographic parameters measured and methods used

\begin{tabular}{|c|c|c|c|}
\hline $\begin{array}{l}\text { No } \\
\text { No }\end{array}$ & $\begin{array}{l}\text { Parameter } \\
\text { Parameters }\end{array}$ & $\begin{array}{c}\text { Satuan } \\
\text { Unit }\end{array}$ & $\begin{array}{c}\text { Alat, metode dan pustaka } \\
\text { Instrument, method and literature }\end{array}$ \\
\hline 1. & Kedalaman air/Water depth & $\mathrm{m}$ & Depth meter, insitu \\
\hline 2. & Kecerahan/Transparency & $\mathrm{cm}$ & Cakram Secchi, in situ \\
\hline 3. & Suhu/Temperature & ${ }^{\mathrm{o}} \mathrm{c}$ & Reversiing Thermometer, in situ \\
\hline 4. & $\mathrm{pH} / p H$ & unit & Titration, indicator universal $p H 4-7 /$ in situ \\
\hline 5. & Salinitas/Salinity & $\%$ & Refraktometer, insitu \\
\hline 6. & Oksigen terlarut/Dissolved oxygen & $\mathrm{mg} / \mathrm{l}$ & $\begin{array}{l}\text { Winkler, insitu, Laboratorium } \\
\text { Hutagalunget al. (1997) }\end{array}$ \\
\hline
\end{tabular}

\section{Analisis Data}

Kelimpahan meroplankton

Kelimpahan meroplankton dihitung dengan menggunakan rumus APHA (2005) yang dimodifikasi, yaitu:

$$
N=\frac{c}{V} \times 1.000
$$

Keterangan /Remarks:

$\mathrm{N}$ : kelimpahan meroplankton/Abundance of meroplankton (Ind/1000 $\mathrm{m}^{3}$ )

$\mathrm{c}$ : jumlah meroplankton yang tercacah dalam sampel/ The number of sample meroplankton be counted (ind)

$\mathrm{V}$ : volume air tersaring/ The volume offiltered water (Vtsr $=1 \times \mathrm{t} \times \mathrm{v}$ )

1 : luas bukaan mulut bongo net/ area of mouth bongo net $\left(\mathrm{m}^{2}\right)$

$\mathrm{t}$ : lama waktu penarikan bongo net/ The length of time of withdrawal bongonet (menit/minute)

v : kecepatan tarikan/ the pull speed of ( $\mathrm{m} /$ menit; $\mathrm{m} /$ minute $)$

\section{Hubungan Antara Kelimpahan Meroplankton dan Kualitas Perairan}

Hubungan antara kelimpahan meroplankton dan kualitas perairan di Teluk dianalisis dengan Principle Component Analysis (PCA) pada software Minitab.ver.16.

\section{HASIL DAN BAHASAN \\ Hasil}

\section{Kelimpahan Meroplankton}

Kelimpahan meroplankton di Teluk Jakarta tahun 2009 bervariasi, tertingggi pada bulan Juni. Kelimpahan meroplankton bulan April berkisar antara 0,2-8.594 ind/ $1000 \mathrm{~m}^{3}$, Juni antara $171-68.585 \mathrm{ind} / 1000 \mathrm{~m}^{3}$, Agustus antara $75-42.711 \mathrm{ind} / 1000 \mathrm{~m}^{3}$ dan Oktober antara 50-18.447 ind/ $1000 \mathrm{~m}^{3}$ (Lampiran 1). Larva udang mendominasi kelimpahan meroplankton pada bulan April-Oktober 2009 (Gambar 2). Secara spasial kelimpahan larva udang yang tinggi terjadi di Muara Gembong, Tanjung Gembong dan Muara Karawang di kawasan timur Teluk Jakarta.

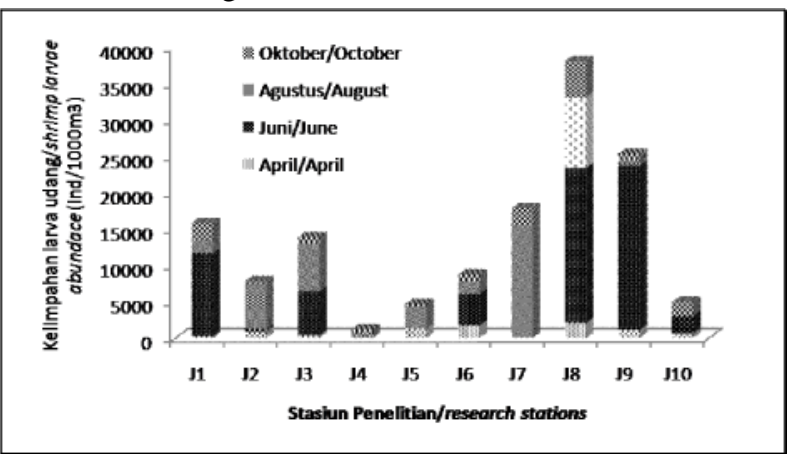

Gambar2. Kelimpahan larva udang di Teluk Jakarta, tahun 2009.

Figure 2. Abundance of shrimp larvae in Jakarta Bay waters on 2009.

Kelimpahan meroplankton di Teluk Jakarta tahun 2010 pada bulan April berkisar antara 5-2908,5 ind $/ 1000 \mathrm{~m}^{3}$, bulan Juni berkisar antara 5,7-3163,7 ind $/ 1000 \mathrm{~m}^{3}$ yang juga didominasi oleh larva udang (Gambar 3).

\section{Komposisi Meroplankton}

Meroplankton yang teridentifikasi pada tahun 2009 dan 2010 sebanyak 4 kelompok yng teridiri dari ikan, telur, udang dan kepiting (Gambar 4 dan 5). Komposisi meroplankton di Teluk Jakarta pada tahun 2009 didominasi oleh larva udang sebesar 56,17-90,40\%, demikian juga pada tahun 2010 didominasi oleh larva udang sebesar 72,1$75,5 \%$. 


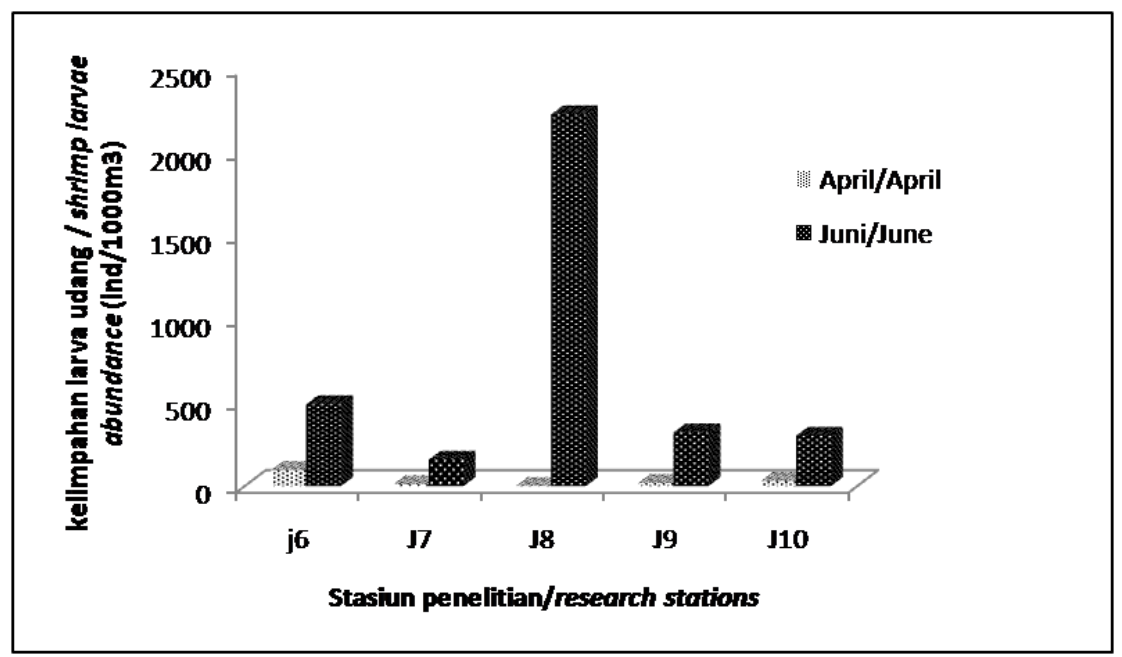

Gambar 3. Kelimpahan larva udang di perairan Teluk Jakarta, 2010.

Figure 3. Abundance of shrimp larvae in Jakarta Bay waters on 2010

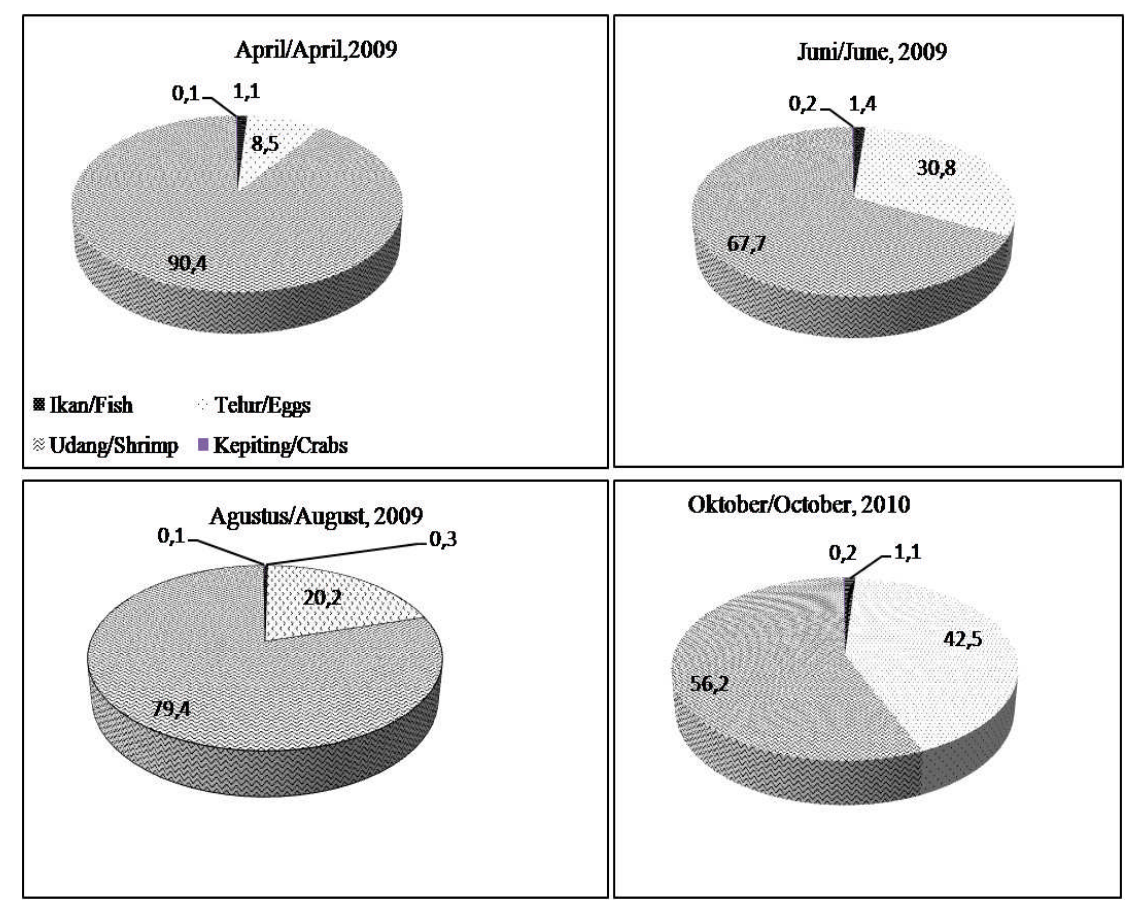

Gambar 4. Komposisi (\%) meroplankton di perairan Teluk Jakarta tahun 2009 Figure 4. Composition (\%) of meroplankton in Jakarta Bay, 2009.

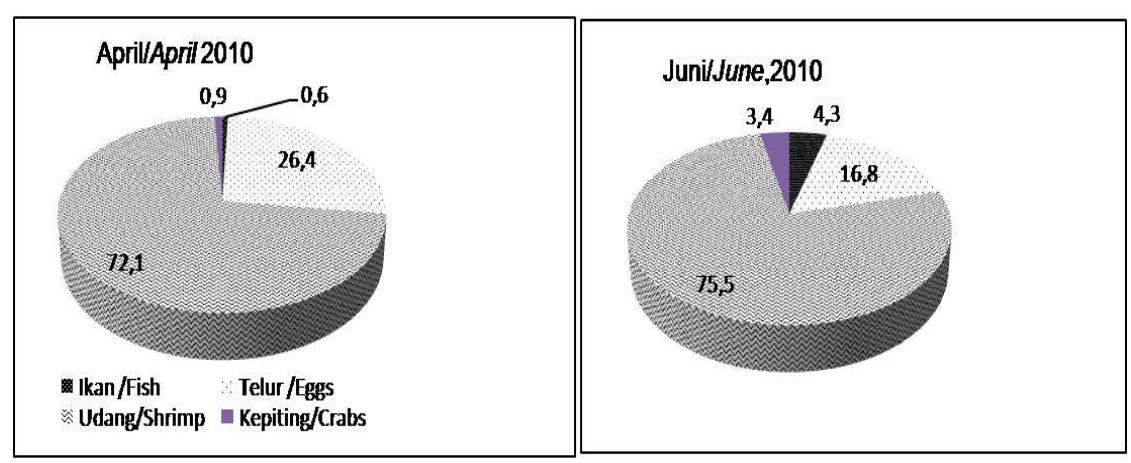

Gambar 5. Komposisi (\%) meroplankton di perairan Teluk Jakarta tahun 2010. Figure 5. Composition (\%) of meroplankton in Jakarta Bay waters 2010. 


\section{Kondisi Kualitas Perairan}

Hasil pengukuran kualitas perairan Teluk Jakarta, tahun 2009 secara rinci dapat dilihat pada Tabel 3. Kecerahan perairan Teluk Jakarta berkisar antara 0,1-1,7 $\mathrm{m}$, suhu air berkisar antara $28,5-33^{\circ} \mathrm{C}, \mathrm{pH}$ di lokasi penelitian berkisar antara 3,7-7,41, kadar oksigen terlarut berkisar antara 2,94-5,64 mg/L dan kadar salinitas berkisar antara $17-35 \%$.

Tabel 3. Kondisi kualitas perairan di Teluk Jakarta tahun 2009

Table 3. Water quality condition of Jakarta Bay on 2009

\begin{tabular}{|c|c|c|c|c|c|c|c|c|c|}
\hline \multirow[t]{2}{*}{ Parameter } & \multirow{2}{*}{$\begin{array}{l}\text { Satuan/ } \\
\text { unit }\end{array}$} & \multicolumn{2}{|c|}{ Apri/April } & \multicolumn{2}{|c|}{ Juni/June } & \multicolumn{2}{|c|}{ Agustus/August } & \multicolumn{2}{|c|}{ Oktober/October } \\
\hline & & $\begin{array}{c}\text { Kisaran/ } \\
\text { Range }\end{array}$ & $\begin{array}{l}\text { Rerata/ } \\
\text { Average }\end{array}$ & $\begin{array}{c}\text { Kisaran/ } \\
\text { Range }\end{array}$ & $\begin{array}{l}\text { Rerata/ } \\
\text { Average }\end{array}$ & $\begin{array}{c}\text { Kisaran/ } \\
\text { Range }\end{array}$ & $\begin{array}{l}\text { Rerata/ } \\
\text { Average }\end{array}$ & $\begin{array}{l}\text { Kisaran/ } \\
\text { Range }\end{array}$ & $\begin{array}{l}\text { Rerata/ } \\
\text { Average }\end{array}$ \\
\hline $\begin{array}{l}\text { Kecerahan/ } \\
\text { Transparency }\end{array}$ & $\mathrm{m}$ & $0,1-1,7$ & 1,08 & $0,3-0,9$ & 0,6 & $0,5-1,2$ & 0,89 & $0,6-1,2$ & 0,88 \\
\hline $\begin{array}{l}\text { Suhu air/ Water } \\
\text { temperature }\end{array}$ & ${ }^{\circ} \mathrm{C}$ & $29,9-31,8$ & 30,7 & $29,9-31,3$ & 30,5 & $28,5-33,0$ & 30,4 & $29,0-32,0$ & 30,2 \\
\hline $\mathrm{pH}$ & unit & $6,2-7,6$ & 6,83 & $7,1-7,4$ & 7,27 & $5-6,9$ & 6,41 & $3,7-7,1$ & 6,15 \\
\hline $\begin{array}{l}\mathrm{O} 2 \text { terlarut/ } \\
\text { dissolved oxygen }\end{array}$ & $\mathrm{mg} / \mathrm{l}$ & $3,7-4,6$ & 4,1 & $3,4-5,6$ & 4,2 & $3,0-5,0$ & 3,9 & $2,9-5,0$ & 4 \\
\hline Salinitas/Salinity & ${ }^{0} / 00$ & $17-31,5$ & 27,83 & Des-29 & 26 & $29-35$ & 30,55 & $29-30$ & 29,9 \\
\hline
\end{tabular}

Kecerahan tertinggi (1,08 m) pada bulan April dan terendah $(0,6 \mathrm{~m})$ pada bulan Juni. Suhu air tertinggi $\left(30,7^{\circ} \mathrm{C}\right)$ pada bulan April dan terendah $\left(30,2^{\circ} \mathrm{C}\right)$ pada bulan Oktober. $\mathrm{pH}$ tertinggi $(7,27)$ pada bulan Juni dan terendah $(6,15)$ pada bulan Oktober. Salinitas tertinggi $(30,55 \%)$ pada bulan Agustus dan terrendah $(26 \%$ ) pada bulan Juni.

Kondisi kualitas Perairan Teluk Jakarta pada Tahun 2010 disajikan pada Tabel 3. Kecerahan perairan bulan April lebih tinggi $(0,8 \mathrm{~m})$ dibandingkan kecerahan bulan Juni $(0,6 \mathrm{~m})$. Suhu air bulan April lebih tinggi $\left(32,2^{\circ} \mathrm{C}\right)$ dibandingkan bulan Juni $(30,9$ $\left.{ }^{\circ} \mathrm{C}\right) . \mathrm{pH}$ bulan April lebih tinggi $(8,3)$ dibandingkan bulan Juni $(7,7)$ dan oksigen terlarut pada bulan April hampir sama lebih dari $5 \mathrm{mg} / \mathrm{L}$. Salinitas pada bulan April lebih rendah $(20,4 \%$ oo $)$ dibandingkan bulan Juni $(28,4 \%)$.

Tabel 4. Kondisi kualitas perairan di Teluk Jakarta, Tahun 2010

Table 4. Water quality condition Jakarta Bay, 2010

\begin{tabular}{|c|c|c|c|c|c|}
\hline \multirow[b]{2}{*}{ Parameter } & \multirow{2}{*}{$\begin{array}{l}\text { Satuan / } \\
\text { unit }\end{array}$} & \multicolumn{2}{|c|}{ April / April } & \multicolumn{2}{|c|}{ Juni/ June } \\
\hline & & $\begin{array}{c}\text { Kisaran / } \\
\text { range }\end{array}$ & $\begin{array}{l}\text { Rerata/ } \\
\text { average }\end{array}$ & $\begin{array}{c}\text { Kisaran/ } \\
\text { range }\end{array}$ & $\begin{array}{l}\text { Rerata/ } \\
\text { average }\end{array}$ \\
\hline Kecerahan/transparency & $\mathrm{m}$ & $0,43-1,1$ & 0,8 & $0,1-1,0$ & 0,6 \\
\hline Suhu air/water temperature & ${ }^{\circ} \mathrm{c}$ & $31-32,7$ & 32,2 & $30-31,6$ & 30,9 \\
\hline $\mathrm{pH}$ & unit & $8,1-8,7$ & 8,3 & $7,5-8,0$ & 7,7 \\
\hline $\mathrm{O} 2$ terlarut/dissolved oxygen & $\mathrm{mg} / \mathrm{l}$ & $4,7-5,8$ & 5,06 & $4-6,5$ & 5,4 \\
\hline Salinitas/salinity & $\%$ & $6-28$ & 20,4 & $24,5-29,9$ & 28,4 \\
\hline
\end{tabular}

Secara umum kondisi perairan di Teluk Jakarta pada tahun 2009 dan 2010 relatif tidak fluktuatif, kecuali kecerahan. Jika dibandingkan antara tahun 2009 dan 2010, terdapat penurunan kecerahan rata-rata sebesar $0,2 \mathrm{~m}$. Hal ini mengindikasikan terjadinya peningkatan kekeruhan air.
Kesesuaian larva udang dengan lingkungan perairan secara rinci disajikan pada Tabel 4 dan hubungan antara kelimpahan larva udang dengan kualitas perairan disajikan pada Gambar 6. 
Tabel 5. Kesesuaian larva udang dengan lingkungan perairan Table 5. Suitability of shrimp larvae with the aquatic environment

\begin{tabular}{|c|c|c|c|c|c|c|c|c|c|}
\hline \multirow[t]{3}{*}{ Parameter } & \multirow[t]{3}{*}{$\begin{array}{l}\text { Satuan/ } \\
\text { unit }\end{array}$} & \multicolumn{4}{|c|}{ Penelitian Tahun 2009/Research 2009} & \multicolumn{2}{|c|}{$\begin{array}{c}\text { Penelitian Tahun } \\
\text { 2010/Research 2010 }\end{array}$} & \multirow{2}{*}{\multicolumn{2}{|c|}{$\begin{array}{l}\text { Kriteria/CrReko mendasi/Rec } \\
\text { iteria o mendation }\end{array}$}} \\
\hline & & \multirow{2}{*}{$\begin{array}{c}\text { Apri/April } \\
\begin{array}{c}\text { Rerata/ } \\
\text { Average }\end{array}\end{array}$} & \multicolumn{2}{|c|}{$\begin{array}{c}\text { Juri/June Agustus/ } \\
\text { August }\end{array}$} & \multirow{2}{*}{$\begin{array}{l}\begin{array}{l}\text { Oktober/ } \\
\text { October }\end{array} \\
\begin{array}{c}\text { Rerata/ } \\
\text { Average }\end{array}\end{array}$} & \multirow{2}{*}{$\begin{array}{c}\text { April/April } \\
\begin{array}{c}\text { Rerata/ } \\
\text { Average }\end{array}\end{array}$} & \multirow{2}{*}{$\begin{array}{c}\text { Juni/June } \\
\begin{array}{l}\text { Rerata/ } \\
\text { Average }\end{array}\end{array}$} & & \\
\hline & & & $\begin{array}{c}\text { Rerata/ } \\
\text { Average }\end{array}$ & $\begin{array}{l}\text { Rerata/ } \\
\text { Average }\end{array}$ & & & & & \\
\hline $\begin{array}{l}\text { Kecerahan/ } \\
\text { Transparency }\end{array}$ & m & 1,08 & 0,6 & 0,89 & 0,88 & 0,6 & 0,58 & $\begin{array}{l}\text { Effendi, } \\
2003\end{array}$ & sesuai/suitable \\
\hline \multirow[t]{2}{*}{$\begin{array}{l}\text { Suhu air/ Water } \\
\text { temperature }\end{array}$} & ${ }^{\circ} \mathrm{c}$ & 30,7 & 30,5 & 30,4 & 30,2 & 32,2 & 30,9 & $\begin{array}{l}\text { Haliman, } 2 \\
005\end{array}$ & 2 sesuai/suitable \\
\hline & unit & 6,83 & 7,27 & 6,41 & 6,15 & 8,3 & 7,7 & $\begin{array}{l}\text { Effendi, } \\
2003\end{array}$ & $\begin{array}{l}\text { kurang } \\
\text { sesuai/less } \\
\text { suitable }\end{array}$ \\
\hline $\begin{array}{l}\mathrm{PH} \text { terlarut/ } \\
\text { disso lued oxygen }\end{array}$ & $\mathrm{mg} / \mathbf{1}$ & 4,1 & 4,2 & 3,9 & 4 & 5,06 & 5,4 & $\begin{array}{c}\text { Tricahyo, } 1 \\
995\end{array}$ & l sesuai/suitable \\
\hline Salinitas/Salinity & ${ }^{0} / 00$ & 27,83 & 26 & 30,55 & 29,9 & 20,4 & 28,4 & $\begin{array}{l}\text { Xincai, } \\
2001\end{array}$ & sesuai/suitable \\
\hline
\end{tabular}

Hubungan Kelimpahan Larva Udang dengan Kualitas Perairan di Teluk Jakarta

Berdasarkan hasil analisis PCA pada Gambar 6, diketahui bahwa kelimpahan larva udang dipengaruhi oleh
$\mathrm{pH}$, salinitas, kecerahan dan suhu air, sedangkan pengaruh oksigen terlarut terhadap kelimpahan larva udang tidak signifikan.

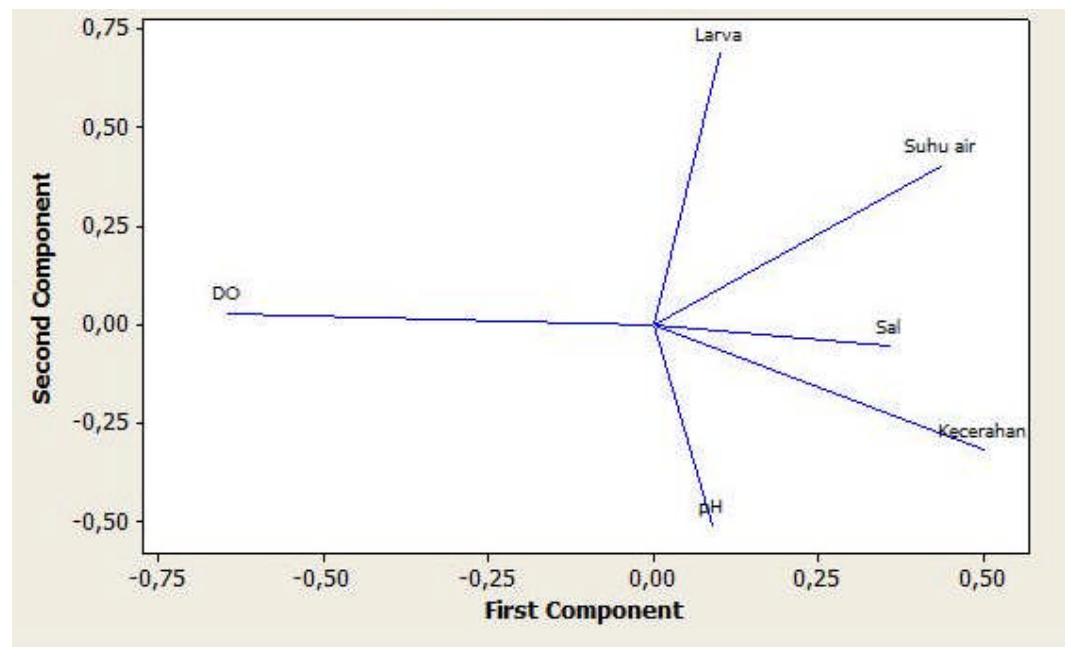

Gambar 6. Hubungan kelimpahan larva udang dengan kualitas perairan di Teluk Jakarta, pada tahun 2009-2010.

Figure 6. Correlation between shrimp larvae abundance and water quality in Jakarta Bay, 2009-2010.

\section{Bahasan}

\section{Komposisi dan Kelimpahan Meroplankton}

Perairan Teluk Jakarta berfungsi sebagai daerah asuhan dan pemijahan bagi berbagai jenis biota laut. Hal ini ditunjukkan dengan ditemukannya meroplankton seperti ikan, telur, udang dan kepiting. Larva udang merupakan kelompok larva yang ditemukan dengan kelimpahan tertinggi dan dijumpai hampir dalam setiap pengamatan. Hasil pengamatan meroplankton tahun 2009 dan 2010 menunjukkan bahwa di perairan Teluk Jakarta dijumpai berbagai jenis meroplankton dari kelompok ikan, telur, udang dan kepiting. 
Udang sebagai biota yang mendominasi komposisi larva pada 2009-2010 juga dibuktikan dari hasil penelitian tahun 2014, di mana lebih dari 90\% kelimpahan larva Teluk Jakarta didominasi udang (Hartati et al., 2015). Jenis larva udang yang mendominasi adalah udang krosok (Penaeus merguensis), udang jerbung (P. monodon), udang kipas (Hapiosquilla annandalei) dan udang rebon (Acetes sp).

Kelimpahan larva udang di Teluk Jakarta pada tahun 2009-2010, lebih tinggi bila dibandingkan dengan kelimpahan larva udang pada tahun 2014. Kelimpahan larva di Teluk Jakarta pada bulan April 2014 berkisar antara 0,8$444,1 \mathrm{ind} / \mathrm{m}^{3}$, dengan komposisi jenis didominansi oleh larva udang, larva moluska dan ikan. Pada bulan Agustus kelimpahan larva berkisar antara 0,01-3,79 ind $/ \mathrm{m}^{3}$, komposisi jenis meroplankton tetap didominasi oleh larva udang.

Penurunan kelimpahan larva udang pada tahun 2014 diduga berhubungan dengan lingkungan perairan saat ini yang semakin terdegradasi, baik kondisi oseanografi maupun ekosistem mangrove. Pusat Penelitian Oseanografi LIPI melaporkan bahwa konsentrasi oksigen pada Desember 2015 hanya mencapai hanya 1,094 mg/l (keadaan normal 4-5 mg per liter). Kadar oksigen minim akibat oleh banyaknya Coscinodiscus spp, kepadatan fitoplankton ini mencapai 1-2 juta sel per liter (Anonimus, 2015). Selain parameter oseanografi, semakin terdegradasinya ekosistem mangrove diduga menjadi faktor rendahnya kelimpahan larva.

Nagelkerken et al. (2000) menyatakan bahwa ketersediaan mangrove merupakan faktor penting sebagai kawasan asuhan bagi biota air terutama udang dan ikan. Bengen (2004) menyatakan bahwa ekosistem mangrove merupakan habitat mencari pakan yang potensial, habitat asuhan dan habitat perlindungan bagi biota perairan terutama larva dan juvenil udang. Tutupan mangrove di bagian timur Teluk Jakarta kurang dari $50 \%$ atau 6,544,43\% (BPLHD DKI Jakarta, 2011; Dinas kehutanan, 2013; Parawansa, 2007 dan Sodikin, 2013) akibat dari alih guna lahan menjadi tambak dan penggunaan kayu mangrove untuk kebutuhan rumah tangga. Di Muara Angke dan Muara Kamal tutupan termasuk dalam kriteria sedang yaitu sekitar 60,75\% , karena kondisi mangrove di kedua daerah dijaga sebagai hutan lindung. Untuk itu diperlukan pengelolaan Teluk Jakarta termasuk hutan mangrove untuk menjaga kerberlangsungan hidup berbagai jenis ikan yang potensial bagi perikanan.

\section{Sebaran dan Kelimpahan Larva Udang}

Sebaran dan kelimpahan larva udang di Teluk Jakarta didukung oleh parameter lingkungan perairan yaitu $\mathrm{pH}$, salinitas, kecerahan dan suhu air. Sesuai dengan Gambar
6, diketahui bahwa tinggi kelimpahan larva udang diduga dipengaruhi oleh nilai $\mathrm{pH}$ yang rendah. Hal ini sesuai dengan hasil penelitian Bir et al. (2015) bahwa pH berkorelasi negatif terhadap kelimpahan larva udang dan larva kepiting. Menurut Damar (2003) dan Arifin (2004) peningkatan kandungan material organik yang merangsang tingginya kelimpahan fitoplankton bahkan bisa terjadi blooming menyebabkan rendahnya $\mathrm{pH}$.

Peningkatan kelimpahan larva udang berkorelasi negatif dengan kecerahan hal ini sesuai dengan hasil kajian Shil et al. (2013) yang menyatakan bahwa kecerahan berkorelasi negatif terhadap larva crustacea. Kelimpahan larva udang berbanding lurus peningkatan suhu air, hal sesuai dengan hasil kajian Arshad et al. (2011) yaitu peningkatan suhu air memiliki korelasi positif terhadap kelimpahan genus Peneaus dan Acetes. Menurut Ayata (2011) distribusi meroplankton di teluk Biscay-N EAtlantic dipengaruhi oleh suhu, salinitas dan khlorofil-a.

\section{KESIMPULAN}

Meroplankton di Teluk Jakarta yang teridentifikasi pada tahun 2009 dan 2010 sebanyak 4 kelompok (ikan, telur, udang dan kepiting). Komposisi meroplankton di Teluk Jakarta tahun 2009 didominasi oleh larva udang sebesar 56,17- 90,40\% dan tahun 2010 sebesar 72,1-75,5 $\%$. Kelimpahan larva udang tahun 2014 lebih rendah dibanding tahun 2009-2010. Hal ini diduga berhubungan dengan semakin terdegradasinya lingkungan perairan saat ini, baik kondisi oseanografi maupun ekosistem mangrove. Kelimpahan larva udang dipengaruhi oleh $\mathrm{pH}$, salinitas, kecerahan dan suhu air

\section{PERSANTUNAN}

Tulisan berjudul "Hubungan antara Kelimpahan Meroplankton dengan Kualitas Perairan di Teluk Jakarta" merupakan bagian dari penelitian Distribusi Spatial dan Temporal Juvenil Udang dan Karakteristik Habitat Secara Horizontal Dalam Rangka Konservasi di Teluk Jakarta. Sumber dana penelitian ini adalah APBN pada tahun anggaran 2009.

\section{DAFTAR PUSTAKA}

Anonimus. (2015). Ini Hasil Uji Lab LIPI Terkait Kasus Jutaan Ikan yang Mati di Ancol. Diakses dari http:// news.detik.com/berita/3085497/ini-hasil-uji-lab-lipiterkait-kasus-jutaan-ikan-yang-mati-di-pantai-ancol.

American Public Health Association (APHA). (2005). Standard Methods for The Examination of Water and Waste Water. (17 $7^{\text {th }}$ ed.). Washington DC, USA: APHA. $1193 \mathrm{pp}$. 
Arifin, Z. (2004). Local Millennium Ecosystem Assessment: Condition and Trends of the Greater Jakarta Bay Ecosystem. Republic of Indonesia: The Ministry of Environment. 30 pp.

Arshad, A., Ara, R., Amin, S., Effendi, M., Zaidi, C. C., \& Mazlan, A. G. (2011). Influence of environmental parameters on shrimp post larvae in the Sungai Pulai seagrass beds of Johor Strait Peninsular Malaysia. Scientific Research \& Essays, 6(26), 5501-5506.

Ayata. S.D., R.Stolba., Thierrycomtet., \& E. Thie'baut. (2011). Meroplankton distribution and its relationship to coastal mesoscale hydrological structure in the northern Bay of Biscay (NE Atlantic).

Bengen, D.G. (2004). Pedoman Teknis Pengenalan dan Pengelolaan Ekosistem Mangrove. Bogor: Pusat kajian Sumberdaya Pesisir dan Lautan IPB.

Bir, J., Sumon, M.S., \& Rahaman, S.M.B. (2015). The effect of different water quality parameters on zooplankton distribution in major river system of Sundarbans mangrove. IOSR Journal of Environmental Science, Toxicology and Food Technology, 9(11), 56-63.

BPLHD DKI Jakarta. (2011). Status lingkungan hidup DKI Jakarta, Kondisi lingkungan hidup dan kecenderungannya. Provinsi DKI Jakarta: Badan Pengelolaan Lingkungan Hidup Daerah. $72 \mathrm{Hal}$.

Damar, A. (2003). Effect on enrichment on nutrient dynamics, phytoplankton dynamics and productivity in Indonesian tropical waters: a comparison between Jakarta Bay, Lampung Bay and Semangka Bay. Dissertation. Kiel, Germany.

Dinas Kehutanan Jawa Barat. (2013). Mangrove. Diakses dari http://www.mongabay.co.id/2013/03/11/ mangrove-muara-gembong-rusak-parah-3-desahilang/ (28 April 2013).

Effendi, H. (2003). Telaah Kualitas Air Bagi Pengelolaan dan Sumberdaya Lingkungan Perairan (p. 258). Yogyakarta: Penerbit Kanisius.

Fachrul, M. F., Haeruman, H., \& Sitepu, L. C. (2005). Komunitas Fitoplankton Sebagai Bio-Indikator Kualitas Perairan Teluk Jakarta. Jakarta: FMIPA Universitas Indonesia.

Hartati, S.T., Puspasari, R., Triharyuni, S., Sulaiman, P.S., Utama, A.A. \& Rahmadi, P. (2015). Kajian perikanan dan lingkungan di Teluk Jakarta. Laporan Akhir. Indonesia: Pusat Penelitian Pengelolaan Perikanan dan Konservasi Sumber Daya Ikan.
Haliman. (2005). Udang Vanamei. Depok: Penebar Swadaya.

Mitchell, C.P. (1994). Whitebait Spawning Ground Management. Science \& Research Series No. 69. Wellington, New Zealand : Department of Conservation.

Nagelkerken, I., Van der Velde, G., Gorrisena, M.W., Meijera, G.J., van't Hofc, T., \& den Hartog, C. (2000). Importance of mangroves, seagrass beds and the shallow coral reef as a nursery for important coral reef fishes, using visual census technique. Estuarine, Coastal and Shelf Science, 51, $31-44$.

Nontji, A. (2008). Plankton Laut (p. 331). Jakarta : LIPI Press.

Nybakken, J. W. (1992). Biologi laut suatu pendekatan ekologis. Jakarta : Gramedia.

Parawansa, I. (2007). Pengembangan kebijakan pembangunan daerah dalam pengelolaan hutan mangrove di Teluk Jakarta secara berkelanjutan. Disertasi (p. 139). Bogor : IPB.

Quist, M. C., Pember, K.R., \& Guy, C.S. (2004). Variation in larval fish communities: implications for management and sampling designs in reservoir systems. Fisheries Management and Ecology 11, 107-116.

Rahman, K. (2011). Hubungan kuantitatif antara fitoplankton dan zooplankton herbivora di perairan Teluk Jakarta pada bulan Agustus dan September 2009. Skripsi (p. 59). Fakultas Matematika dan Ilmu Pengetahuan Alam. Departemen Biologi. Universitas Indonesia.

Romimoharto, K., \& Juwana, S. (2004). Meroplankton laut-larva hewan laut yang menjadi plankton. Jakarta : Djambatan.

Soedibjo, B.S. (2006). Struktur komunitas fitoplankton dan hubungannya dengan beberapa parameter lingkungan di Perairan Teluk Jakarta. Oseanologi dan Limnologi di Indonesia 40, 65-78.

Shoji, J. \& Tanaka, M. (2008). Recruitment processes of japanese sea bass in the Chikugo, Japan: shift from density-independence to density-dependence during the early life stages. J. Northw. Atl.Fish.Sci.41, 85-91.

Shil, J., Ghosh, A.K., \& Rahaman, S.M.B. (2013). Abundance and diversity of zooplankton in semi intensif prawn (Macrobrachium rosenbergii) farm. Spingerplus 2, 183. 
Sodikin. (2013). Kerusakan mangrove serta korelasinya terhadap tingkatan intrusi laut (studi kasus di desa Pantai Bahagia Kecamatan Muara Gembong, Kabupaten Bekasi. Tesis (p. 69). Semarang: Program Magister Ilmu Lingkungan. Pasca Sarjana. Universitas Diponegoro.

Tricahyo, E. (1995). Biologi dan Kultur Udang Windu. Jakarta: Akapress.
Van der Lingen, C.D., \& Huggett, J.A. (2003). The role of ichthyoplankton surveys in recruitmen research and management of South African anchovy and sardine. Proceedings of the 26th Annual Larval Fish Confference. Norway.

Xincai, C., \& Yongquan, S. (2001). Shrimp culture. China Internasional Training Course on Technology of Marineculture (Precious Fishes). China: Yiamen Municipal Sciense \& Technology Commission. pp. 107113. 
Lampiran 1. Kelimpahan meroplankton dan kualitas perairan di Teluk Jakarta, 2009-2010 Appendix 1. Abundance of meroplankto and water quality in Jakarta Bay, 2009-2010.

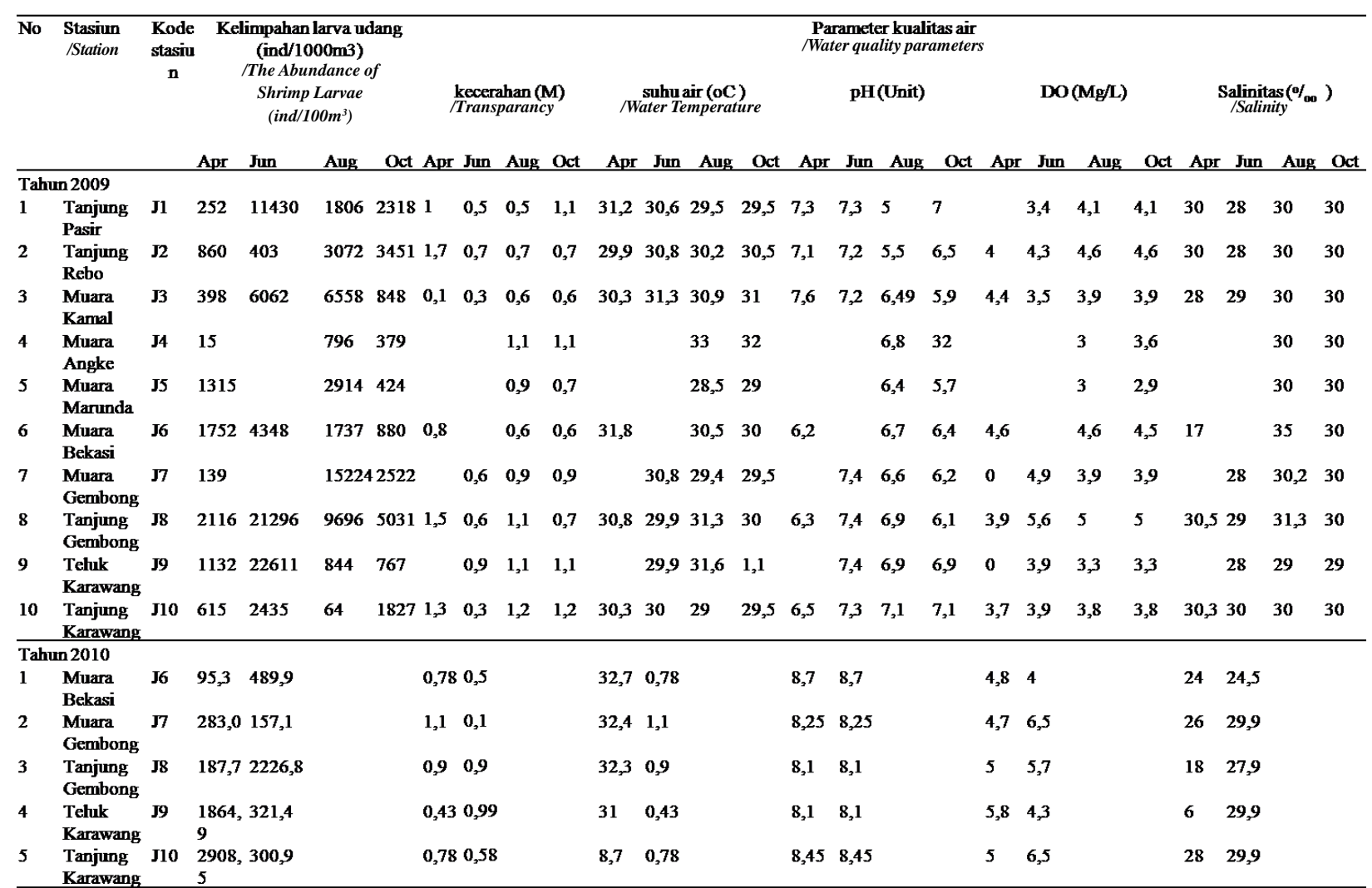

